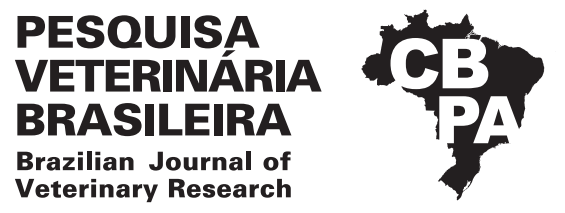

Pesq. Vet. Bras. 38(8):1685-1690, agosto 2018 DOI: 10.1590/1678-5150-PVB-5025

Original Article

Morfofisiologia/Morphophysiology

ISSN 0100-736X (Print)

ISSN 1678-5150 (Online)

\title{
Determination of the reference interval for the activity of N-Acetyl- $\beta$-D-Glucosaminidase (NAG) in urine of healthy dogs ${ }^{1}$
}

\author{
Luiz Eduardo S. Tassini ${ }^{2 *}$ Fabiola O.P. Leme² ${ }^{2}$ Júlio César C. Veado ${ }^{2}$ \\ and Márcio H.L. Arndt ${ }^{3}$
}

\begin{abstract}
Tassini L.E.S., Leme F.O.P., Veado J.C.C. \& Ardnt M.H.L. 2018. Determination of the reference interval for the activity of NAcetyl- $\beta$-D-glucosaminidase (NAG) in urine of healthy dogs. Pesquisa Veterinária Brasileira 38(8):1685-1690. Departamento de Clínica e Cirurgia Veterinárias, Escola de Veterinária, Universidade Federal de Minas Gerais, Campus Pampulha, Av. Antônio Carlos 6627, São Luiz, Belo Horizonte, MG 31270-901, Brazil. E-mail: tassini.luiz@gmail.com

The diagnosis of acute kidney injury by evaluating the activity of urinary enzymes is an important tool especially for its precocity in relation to methods of assessment of renal function considered late as the installation of injury precedes the function change. This study was performed to determine the reference interval for urinary NAG activity ( $N$-Acetyl- $\beta$-D-glucosaminidase) in urine of healthy dogs of different breeds, ages and sexes. It was utilized an automated method for the determination of NAG activity standardized for dog urine samples. Through statistical analysis it was observed that NAG is positively correlated with the age of the animal and urine specific gravity but is not interfered by sex or weight. Based on the determination of urinary activity and after correcting the values for a 1,025 urine specific gravity was obtained an reference interval of $X^{\prime}=3.62 \mathrm{U} / \mathrm{L} \pm 0.66 \mathrm{U} / \mathrm{L}$.
\end{abstract}

INDEX TERMS: Reference interval, NAcetyl- $\beta$-D-glucosaminidase, NAG, urine, dogs, enzimury, injury.

RESUMO.- [Determinação de intervalo de referência para a atividade da NAcetyl- $\beta$-D-glucosaminidase (NAG) na urina de cães sadios.] $O$ diagnóstico da injúria renal aguda pela avaliação da atividade de enzimas urinárias é uma importante ferramenta para o médico veterinário, especialmente por sua precocidade em relação aos métodos de avaliação da função renal, considerados tardios, visto que a instalação da injúria precede a alteração da função. Neste estudo foi realizada a determinação do intervalo de referência médio para a atividade urinária de NAG (N-Acetyl- $\beta$-D-Glucosaminidase), em urinas de cães hígidos, de diferentes raças, sexos e faixas etárias. Para isso, trabalhou-se com um método automatizado para determinação da atividade de NAG, padronizado para

\footnotetext{
${ }^{1}$ Received on June 2, 2017.

Accepted for publication on July 19, 2017.

Master of Science Dissertation.

${ }^{2}$ Departamento de Clínica e Cirurgia Veterinárias, Escola de Veterinária, Universidade Federal de Minas Gerais (UFMG), Campus Pampulha, Av. Antônio Carlos 6627, São Luiz, Belo Horizonte, MG 31270-901, Brazil. *Coresponding author: tassini.luiz@gmail.com

${ }^{3}$ Labtest, CDICT, Rua Professor José Vieira de Mendonça 770, Engenho Nogueira, Belo Horizonte, MG 31310-260.
}

amostras de urina de cães. Por meio de análise estatística, observou-se que a NAG apresenta correlação positiva com a idade do animal e com a densidade urinária, mas não sofre interferência quanto ao sexo ou peso. Com base na determinação da atividade urinária e após corrigir os valores para uma densidade de 1,025 , obteve-se um intervalo de referência médio de $X^{\prime}=3,62 \mathrm{U} / \mathrm{L} \pm 0,66 \mathrm{U} / \mathrm{L}$.

TERMOS DE INDEXAÇÃO: Intervalo de referência, NAcetyl- $\beta$ D-glucosaminidase, NAG, urina, cães, enzimúria, injúria.

\section{INTRODUCTION}

For a long time the approaches for the nephropathy patients have been related to the evaluations of renal functions using tests that identify an impairment of cellular excretion, reabsorption or secretion. Such tests have as a common characteristic to only identify alterations when about 66 to $75 \%$ of nephrons of both kidneys are compromised. This fact reveals a delayed identification characteristic and it can often be impossible to reverse an established condition which can permanently compromise renal function. Patients 
under these conditions have a limited life at risk of triggering moments of homeostatic imbalance with lower expectations and quality of life. For many of these patients only remain the dialytic treatments and renal transplantation.

The term acute kidney injury (AKI) attempts to reach a group of patients with severe or non severe renal function impairment but without clinical or laboratorial signs of renal failure. As examples of injury it is possible to mention ischemic or toxic glomerulonephritis or tubular injuries (Santos 2014). It is known that kidney injury can lead to changes in function. Serum concentrations of urea and creatinine are markers of excretory function and even if its values are within their reference range, kidney injury may occur. This fact justifies the need for evaluation methods that identify kidney injury (Chew et al. 2011, Santos 2014).

Unlike urea and creatinine which can be considered as late markers of evaluation there are other markers with the quality of evidencing cellular renal damage like urinary enzymes. Because different portions of the nephron contain characteristic enzymes, these enzymes can be used to locate and identify the injury through its increased activity (Veado et al. 2010). In dogs urinary enzymes have been primarily used in the evaluation of acute nephrotoxicity because they are sensitive and non-invasive tests for the diagnosis of tubular lesion (Veado et al. 2010). It is observed a low activity of urinary enzymes in healthy animals and finding an increase in its activity indicates a kidney injury (Veado et al. 2010).

$\mathrm{N}$-Acetyl- $\beta$-D-Glucosaminidase (NAG) is a lysosomal enzyme present at high concentrations in the proximal renal tubules cells. Its molecular weight is $140 \mathrm{kDa}$ which does not allow glomerular filtration (Sato et al. 2002a). If it is observed an increase of the enzime activity above its reference it can be considered that there is a renal parenchymal injury. According to Sato et al. (2002a) the increase of NAG activity in urine is one of the most sensitive indicators of tubular injury. This finding may alter the clinical conduct in order to avoid the progression of the injury and possible renal failure (Heiene et al. 2001). It is known that for identifying AKI or monitoring a preexisting injury it is recommended to execute an urinary panel with early markers that complement each other. Although the evaluation of only one marker represents a limited diagnosis NAG has been shown to be very promising (De Loor et al. 2013). There are no comercial tests in Brazil for analysis of urinary NAG in dogs. In veterinary medicine the researchers use human tests to analise NAG such as Shionogi, Osaka/Japan (Noto et al. 1983). The lack of standardization of biomarker assays hinders the comparison of validation results in dogs (De Loor et al. 2013). Tassini (2015) adapted an automated spectrophotometric assay to evaluate the urinary activity of NAG in dogs. The determination of the reference interval for a given analyte in a species allows the identification of biochemical changes in the evaluated patient, providing the clinician with adequate treatment and prognostic prediction (Williamson et al. 2014).

The objective of this study was to determine the reference interval for urinary NAG activity in samples of healthy dogs of different sexes, races and age groups using the method proposed by Tassini (2015) and approved by the Ethics Committee in Experimentation Animal (CETEA/UFMG), Protocol number 373/2015.

\section{MATERIALS AND METHODS}

Sample population. 60 healthy dogs (Canis familiaris) were selected, aged between 3 months and 15 years old clinically healthy, of different races, both sexes, castrated and from private tutors and support groups to abandoned dogs from the metropolitan area of Belo Horizonte. The 60 dogs included in the study fulfilled all the established prerequisites from an anamnesis questionnaire and clinical, laboratory and ultrasound examinations. The owners of the animals after proper orientation signed a Free and Informed Consent Form and had the right to remove them from the experiment at any time. The criteria for inclusion of the animals were:

- Do not be pregnant or breastfeeding;

- Be clinically healthy at the time of clinical examination and collection of blood and urine samples;

- Not have been subjected to the use of potentially nephrotoxic medications in the last 4 months;

- Have serum concentrations of urea, creatinine, GGT, phosphorus, proteins and fractions and potassium within the reference ranges for the species;

- No haematological changes classified as pathological;

- Do not present alterations in routine urine examination classified as pathological.

- A urinary protein/creatinine ratio of less than or equal to 0.25;

- Animals that did not meet all the necessary requirements were excluded from the project.

Division of groups. The animals selected were divided into three groups, based on age and sex. Each group consisted of 20 individuals, 10 males and 10 females, classified according to age (Table 1).

Tests, sample collection and send to analysis. Urine sample collection was realized by cystocentesis with urine collecting flask attached to a $25 \times 7$ gauge needle $\left(\right.$ Sarstedt ${ }^{\circledR}$ ) guided by abdominal ultrasonography, after previous trichotomy and local antisepsis with $70 \%$ alcohol. The samples were identified and refrigerated immediately after collection until they were sent to the laboratory within a maximum of 4 hours. For the ultrasound examination a linear transducer at the $9 \mathrm{MHz}$ frequency coupled to the Chison $8100 \mathrm{Vet}^{\circledR}$ ultrasound equipment was used as a tool to guide cystocentesis. After urinalysis the urine samples were homogenized and centrifuged in a macrotubes centrifuge for 5 minutes at 2000 RPM (Celm ${ }^{\circledR}$ ) in conical tubes where the supernatant was separated. The supernatant was used for the biochemical determinations in the Cobas Mira Plus ${ }^{\circledR}$, Roche automation equipment.

Determination of the reference interval of urinary NAG. The analysis of the urinary NAG activity was performed by automated spectrophotometric assay in Cobas Mira Plus ${ }^{\circledR}$, Roche biochemical

Table 1. Division of groups of dogs participating in the evaluation study of urinary NAG activity

\begin{tabular}{ccccc}
\hline \multirow{2}{*}{ Group } & n Total* & \multicolumn{2}{c}{ Sample size according to } \\
& & Male & Female & \multirow{2}{*}{ Age (years) } \\
\cline { 3 - 4 } & 20 dogs & 10 & 10 & 3 months -2 \\
I & 20 dogs & 10 & 10 & $3-7$ \\
II & 20 dogs & 10 & 10 & $>7$
\end{tabular}


apparatus according to a technique described by Tassini (2015). The maximum collection period was 4 hours and the samples were kept under refrigeration temperature $\left(4-8^{\circ} \mathrm{C}\right)$ until the time of processing.

Correction of urinary specific gravity. The correction was made for a urinary specific gravity of 1,025 based on the formula proposed by Deschepper et al. (1989): X=Y (25/Z):

- " $X "$ is the value of the urinary enzyme activity after correction by the formula;

- $\quad$ "Y" is the value of the urinary enzyme activity obtained without correction;

- " "Z" corresponds to the last two digits of the sample urine specific gravity value.

Statistical analysis. The determination of the reference interval for NAG was performed by averaging confidence interval analysis using Principal Component Analysis (PCA) with SPPS ${ }^{\circledR}$ v17 software.

\section{RESULTS AND DISCUSSION}

An important point for determination of urinary enzyme activity is the influence of endogenous and exogenous factors on the evaluated sample. Therefore, it is important to exclude such interference so that a reliable urinary output can be obtained. It has been observed in dogs (Sato et al. 2002b) that NAG activity is not increased when there is urinary tract infection or bacteria in the urine. Smets et al. (2010a) observed that the urinary activity of NAG was not affected by the presence of pyuria, hematuria and bacteriuria. This differs from that observed with urinary GGT which, according to Beck \& Sammons (1975), may suffer a decrease in activity in the presence of bacteria. However in order to avoid this kind of interference in this experiment all urine samples were collected by cystocentesis in order to reduce contamination of the sample by the bacterial flora present in the genitals and urethra, which could occur in collections performed by micturition or by collection with an urethral catheter. In addition, the urine samples were centrifuged and then their respective sediments were analyzed under optical microscopy to exclude the presence of bacterial contamination which could be due to a urinary tract infection of the animal under study.

The time of sample collection is also important. Urinary NAG activity shows a small variation throughout the day but not statistically significant (Uechi et al. 1998). For the purpose of standardization and to facilitate the laboratory routine the urine samples were always collected between 8:00 and 11:00 hours. The bitches that were in this experiment could not be pregnant, because according to Semczuk-Sikora et al. (2000), NAG shows increased urinary activity in the third trimester of pregnancy in pregnant women. This physiological variation can occur due to hypertrophy or hyperplasia of nephrons, which change as a form of adaptation to gestation. Nephrons return to normal after gestation when it occurs without complications (hypertension and eclampsia) (Semczuk-Sikora et al. 2000). In this study it was observed that the weight and sex did not influence the results of NAG activity which can be observed in the uniform distribution of the results and that is in agreement with the one observed in humans (Liangos et al. 2007). However there was a positive correlation of NAG activity (Fig.1-3) with the age of the animals evaluated $(\mathrm{p}<0.001)$. Older animals, males and females, of different breeds, presented greater urinary NAG activity according to their age. This correlation observed in healthy dogs is in agreement with that observed in humans by Kono et al. (1990). In their experiment, the urinary NAG activity was evaluated in 1.152 male and female individuals and an increase in the urinary NAG activity was observed with increasing age. Nevertheless, Smets et al. (2010b) evaluating the activity of NAG in healthy dogs and dogs with chronic kidney disease did not observe a positive correlation of NAG with the age of the healthy individuals evaluated, which is in disagreement with the observed in this study. However, this may be due to the fact that the effect of

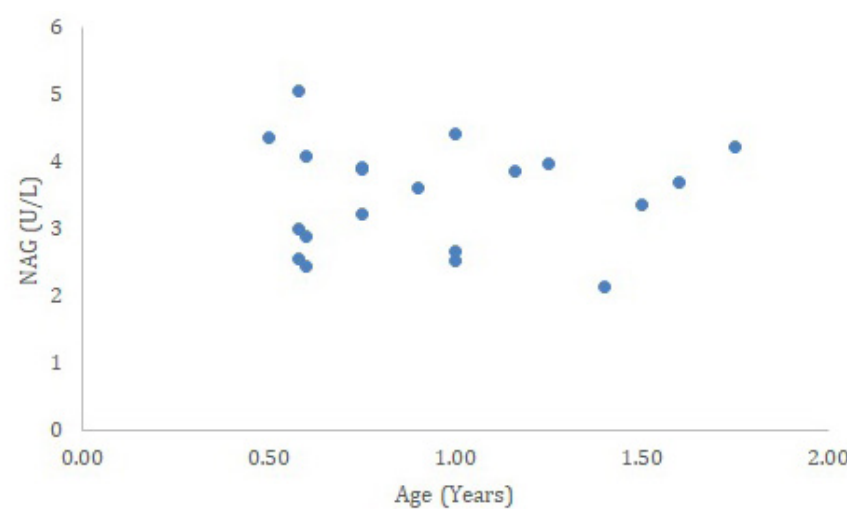

Fig.1. Variation of urinary NAG activity in dogs from 3 months to 2 years old.

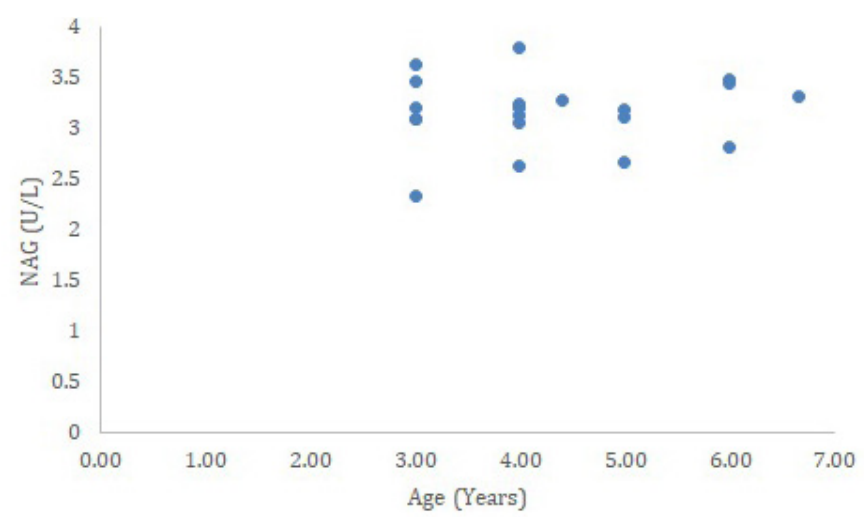

Fig.2. Variation of urinary NAG activity in dogs from 2 to 7 years old.

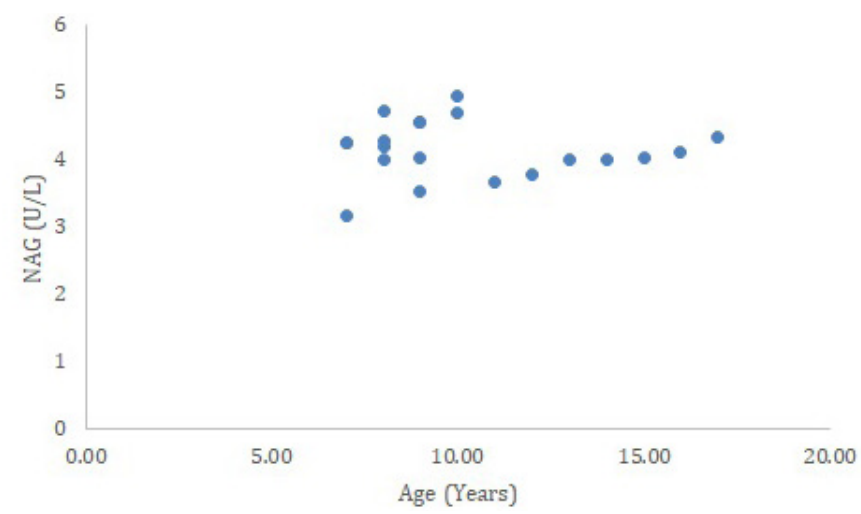

Fig.3. Variation of urinary NAG activity in dogs over 7 years old. 
age is better evaluated in a longitudinal follow-up study of the same individual (Skalova \& Chladek 2004).

Urinary specific gravity is a factor that can lead to variable results in NAG activity. According to Stockham \& Scott (2011), urinary specific gravity is an accurate estimate of the concentration of solutes in urine, so its variation is accompanied by changes in the concentration of diluted solutes in the urine, resulting in a direct influence on the activity values of different enzymes, including NAG. The method used to correct the interference of urinary specific gravity in this study was the use of a formula proposed by Deschepper et al. (1989). This formula defines an urinary specific gravity of 1,025 (considered a normal value for dogs with free access to water intake) as a correction factor for the urinary flow of a single sample. This method of correction was chosen because it is simple to perform and provides reliable results (Scott \& Stockham 2011).

It was observed that NAG activity obtained from samples without the use of the urinary specific gravity correction formula differed statistically from the corrected NAG activity $(p<0.01)$, signaling to the importance of this correction before evaluating a result. The urinary activity of NAG, since there was no significant difference between the sexes (Table 2), after correction, presented a reference interval of $\mathrm{X}=3.62 \mathrm{U} / \mathrm{L} \pm 0.66 \mathrm{U} / \mathrm{L}$, lower than that obtained without correction for urinary specific gravity $(X=5.55 \pm 1.39 \mathrm{U} / \mathrm{L})$.

It is observed that when applied the urinary specific gravity correction formula, the standard deviations of NAG activity are smaller when compared to the values obtained in the same samples but without applying the formula of correction to an urinary specific gravity of 1,025, as shown in Figure 4 and 5. After working with a standardized methodology and excluding interference factors on the analysis, it was necessary to choose an appropriate " $n$ " sample. The aim of this study was to determine a reference interval so to qualify the dogs as healthy it were done complete anamnesis, clinical examination, blood and urine tests and ultrassonography. In addition, it is important to work with an adequate number of animals to be able to determine the reference interval. The statistical method used to determine the reference interval was the multivariate analysis using principal component analysis (PCA), described by Mingotti (2013), for which a minimum number of 50 observations is necessary.

The analysis of urinary NAG activity has been performed in humans using commercial tests for urinary spectrophotometry, usually with the substrate 4-Methylumbelliferyl $\mathrm{N}$-acetyl- $\beta$-D-glucosaminide, as described by Shionogi, Osaka, Japan (Noto et al. 1983). In veterinary medicine, urinary NAG tests have been conducted using commercially available human tests, such as Sanko Junyaku Co. Ltd, Japan, which uses p-nitrophenyl-N-Acetyl- $\beta$-D-glucosaminidase as the substrate however, this may vary according to the test.

In studies such as the one performed by Sato et al. (2002b), p-nitrophenyl-N-Acetyl- $\beta$-D-glucosaminidase was used as a substrate in a test for urinary NAG analysis for humans to determine urinary NAG activity in dogs. A total of 48 dogs were evaluated; however, only 28 were healthy, and a reference interval of 3.2 $2.4 \mathrm{U} / \mathrm{l}$ for urinary NAG was determined. In 2009, Brunker et al. (2009). Evaluated the urinary activity of NAG in 38 healthy dogs of different sexes and age groups using a test for human NAG analysis and obtained a range of
0.02 to $3.63 \mathrm{U} / \mathrm{l}$. In these studies it is not possible to consider that a normal range for the urinary enzyme activity was determined. At the first studie 28 samples were evaluated and in the other 38, both numbers below the minimum required of 50 observations (Mingotti 2013).

The evaluation of a reduced number of observations may not allow to determine a reference interval for a given parameter, keeping the mean urinary activity different from that observed in this experiment. In addition, the $\mathrm{pH}$, temperature or substrate concentration used in these tests are not described, and those are factors that are known to affect the enzymatic reaction (Knoll et al. 1980, Horak et al. 1981), which may increase or reduce the urinary activity evaluated. In the method proposed by Tassini (2015), it was determined an adequate $\mathrm{pH}$ for the enzymatic reaction in urine of dogs, optimum temperature and correction factor based on a specific

Table 2. Reference interval of urinary NAG activity for dogs according to sex

\begin{tabular}{ccc}
\hline \multirow{2}{*}{$\begin{array}{c}\text { Level of statistical } \\
\text { significance }\end{array}$} & \multicolumn{2}{c}{ Reference interval } \\
\cline { 2 - 3 } $95 \%$ & $3.43-3.91$ & Female \\
\hline $99 \%$ & $3.47-3.87$ & $3.36-3.81$ \\
$99.9 \%$ & $3.36-3.98$ & $3.41-3.76$ \\
\hline
\end{tabular}

There was no statistical difference $(\mathrm{P}>0.05)$.

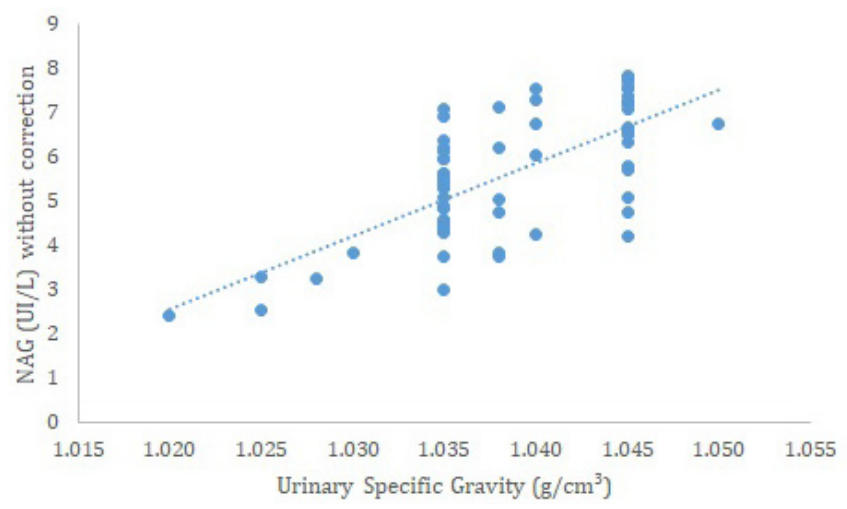

Fig.4. Variation of urinary NAG (U/L) activity without correction of urinary specific gravity $(\mathrm{g} / \mathrm{cm} 3)$.

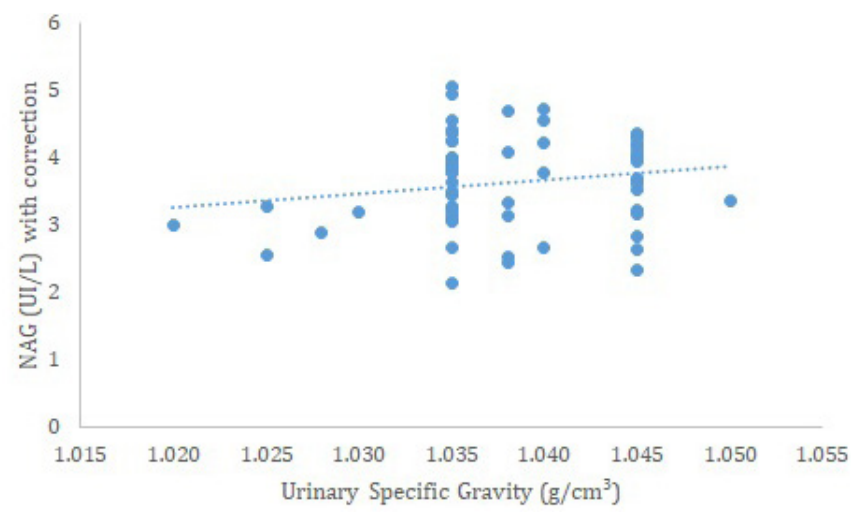

Fig.5. Variation of urinary NAG (U/L) activity with correction of urinary specific gravity $(\mathrm{g} / \mathrm{cm} 3)$. 
absorptivity coefficient. According to De Loor et al. (2013), it is necessary to have adequate standardization of the tests of new biomarkers for dogs, in order to allow a reliable validation of results. NAG has important characteristics that justify its use as a diagnostic method, being a marker capable of signaling AKI with great specificity and precocity (Katagiri et al. 2012). Early signaling of AKI allows the clinician to take preventive therapeutic measures, besides helping to diagnose the type of lesion - whether glomerular or tubular. The use of these biomarkers may be a tool to avoid the progression and worsening of the patient's condition and to guarantee a greater survival (De Loor et al. 2013). In addition, it also serves as a resource for monitoring persistent renal injury in situations where only its urinary activity is assessed or associated with another early marker in patients with chronic kidney disease (Liangos et al. 2007, Smets et al. 2010a, Katagiri et al. 2012). In veterinary medicine, the evaluation of the urinary activity of this enzyme has been restricted to research (Sato et al. $2002 \mathrm{~b}$ ). In this study, the evaluation of urinary NAG activity in dogs with kidney injury was not performed and, therefore, it was not possible to compare its efficacy as an early marker of kidney injury in relation to urinary GGT and other markers, because it was not an objective of this experiment. However, it is known the importance of performing an urinary panel, with different biomarkers, that can provide complementary information about the installed injury and its situation at the moments evaluated (De Loor et al. 2013). For this, it is essential to perform more studies with new biomarkers, with standardization of an adequate methodology and validation of results considering different kidney pathologies.

\section{CONCLUSIONS}

There is a positive correlation between urinary specific gravity and urinary NAG activity.

The urinary activity of NAG varies in a positive way with age.

The use of the urinary specific gravity correction formula to 1,025 reduces the interference of the urinary specific gravity variation of the evaluated sample.

\section{REFERENCES}

Beck P.R. \& Sammons H.G. 1975. A stabilising factor for $\gamma$-glutamyl transpeptidase in urine. Clin. Chim. Acta 65(3):351-359. <http://dx.doi. org/10.1016/0009-8981(75)90261-2><PMid:1162>

Brunker J.D., Ponzio N.M. \& Payton M.E. 2009. Indices of urine N-acetylbeta-D-glucosaminidase and gamma-glutamyl transpeptidase activities in clinically normal adult dogs. Am. J. Vet. Res. 70(2):297-301. <http:// dx.doi.org/10.2460/ajvr.70.2.297><PMid:19231965>

Chew D.J., Dibartola S.P. \& Schenck P.A. 2011. Urologia e Nefrologia do Cão e do Gato. Elsevier, Rio de Janeiro.

De Loor D.S., Daminet S., Smets P., Maddens B. \& Meyer E. 2013. Urinary biomarkers of acute kidney injury in dogs. J. Vet. Intern. Med. 27(5):9981010. <http://dx.doi.org/10.1111/jvim.12155><PMid:23952327>

Deschepper J., Cock I. \& Capiau E. 1989. Urinary gamma-glutamyl transferase and the degree of renal dysfunction in 75 bitches with pyometra. Res. Vet. Sci. 46(3):396-400. <PMid:2568010>

Heiene R.L., Moe L. \& Mølmen G. 2001. Calculation of urinary enzyme excretion, with renal structure and function in dogs with pyometra. Res. Vet. Sci. 70(2):129-137. <http://dx.doi.org/10.1053/rvsc.2000.0451> $<$ PMid:11356092>
Horak E., Hopfer S.M. \& Sunderman Junior F.W. 1981. Spectrophotometric assay for urinary N-Acetyl- $\beta$-D-glucosamiidase activity. Clin. Chem. 27(7):1180-1185. <PMid:7237781>

Katagiri D., Doi K., Honda K., Negishi K., Fujita T., Hisagi M., Ono M., Matsubara T., Yahagi N., Iwagami M., Ohtake T., Kobayashi S., Sugaya T. \& Noiri E. 2012. Combination of two urinary biomarkers predicts acute kidney injury after adult cardiac surgery. Ann. Thorac. Surg. 93(2):577-583. <http://dx.doi. org/10.1016/j.athoracsur.2011.10.048><PMid:22269724>

Knoll E., Wisser H. \& Rautenstrauch H. 1980. Comparative study of the diagnostic value of disc electrophoresis of urine proteins and measurement of the excretion of $\mathrm{N}$-acetylglucosaminidase for the detection of renal tubule damage in chronic polyarthritis. J. Clin. Chem. Clin. Biochem. 18(1):53-58. $<$ PMid:7359091>

Kono K., Yoshida Y., Watanabe M., Watanabe H., Inoue S., Tanioka Y., Dote T., Orita Y., Umebayashi K., Tanimura Y., et al. 1990. Serum and urinary $\mathrm{N}$-acetyl-beta-D-glucosaminidase activity among the inhabitants of a rural area in Japan--the effect of age and hypertension. Bull. Osaka Med. Coll. 36(1/2):27-34. <PMid:2135642>

Liangos O., Perianayagam M.C., Vaidya V.S., Han W.K., Wald R., Tighiouart H., MacKinnon R.W., Li L., Balakrishnan V.S., Pereira B.J., Bonventre J.V. \& Jaber B.L. 2007. Urinary N-acetyl-beta-(D)-glucosaminidase activity and kidney injury molecule-1 level are associated with adverse outcomes in acute renal failure. J. Am. Soc. Nephrol. 18(3):904-912. http://dx.doi. org/10.1681/ASN.2006030221. PMid:17267747.

Mingotti A.S. 2013. Análise de Dados Através de Estatística Multivariada: uma abordagem aplicada. Ed. UFMG, Belo Horizonte. 297p.

Noto A., Ogawa Y., Mori S., Yoshioka M., Kitakaze T., Hori T., Nakamura M. \& Miyake T. 1983. Simple, rapid spectrophotometry of urinary N-acetylbeta-D-glucosaminidase, with use of a new chromogenic substrate. Clin. Chem. 29(10):1713-1716. <PMid:6616814>

Santos K.K.F. 2014. Guia Prático de Nefrologia em Cães e Gatos. LF Livros, Rio de Janeiro.

Sato R., Soeta S., Syuto B., Yamagishi N., Sato J. \& Naito Y. 2002a. Urinary excretion of $\mathrm{N}$-acetyl-beta-D-glucosaminidase and its isoenzymes in cats with urinary disease. J. Vet. Med. Sci. 64(4):367-371. <http://dx.doi. org/10.1292/jvms.64.367><PMid:12014584>.

Sato R., Soeta S., Miyazaki M., Syuto B., Sato J., Miyake Y., Yasuda J., Okada K. \& Naito Y. 2002b. Clinical availability of urinary N-acetyl-beta-D-glucosaminidase index in dogs with urinary diseases. J. Vet. Med. Sci. 64(4):361-365.<http:// dx.doi.org/10.1292/jvms.64.361><PMid:12014583>

Semczuk-Sikora A., Sikora P. \& Semczuk M. 2000. Urinary N-acetyl-beta-Dglucosaminidase (NAG) activity in women with preeclampsia. Ginekol. Pol. 71(3):141-145. <PMid:10842915>

Skalova S. \& Chladek J. 2004. Urinary N-acetyl-beta-D-glucosaminidase activity in healthy children. Nephrology, Carlton 9(1):19-21.<http://dx.doi. org/10.1111/j.1440-1797.2003.00217.x><PMid:14996303>

Smets P.M., Meyer E., Maddens B., Duchateau L. \& Daminet S. 2010a. Effect of sampling method and storage conditions on albumin, retinolbinding protein, and $\mathrm{N}$-acetyl-b-D-glucosaminidase concentrations in canine urine samples. J. Vet. Diagn. Invest. 22(6):896-902. http://dx.doi. org/10.1177/104063871002200607. PMid:21088172.

Smets P.M.Y., Meyer E., Maddens B.E., Duchateau L. \& Daminet S. 2010b. Urinary markers in healthy young and aged dogs and dogs with chronic kidney disease. J. Vet. Intern. Med. 24(1):65-72. <http://dx.doi. org/10.1111/j.1939-1676.2009.0426.x><PMid:20041990>

Stockham S.L. \& Scott M.A. 2011. Fundamentos de Patologia Clínica Veterinária. $2^{\underline{a}}$ ed. Guanabara Koogan, Rio de Janeiro, p.368-375.

Tassini L.E.S. 2015. N-Acetyl-ß-D-Glucosaminidase (NAG): padronização de ensaio espectrofotométrico automático em urina de cães. Dissertação de Mestrado, Escola de Veterinária, Universidade Federal de Minas Gerais, Belo Horizonte. 67p. 
Uechi M., Uechi H., Nakayama T., Wakao Y., Ogasawara T., Takase K. \& Takahashi M. 1998. The circadian variation of $\mathrm{N}$-acetyl- $\beta$-D-glucosaminidase and $\gamma$-glutamyl transpeptidase in clinically healthy cats. J. Vet. Med. Sci. 60(9):1033-1034. http://dx.doi.org/10.1292/jvms.60.1033. PMid:9795907.

Veado J.C.C., Rocha D.F., Cobucci G.C., Melo M.M., Bandeira C.M. \& Paes P.R.O. 2010. $\gamma$-Glutamiltransferase urinária, proteína urinária e fósforo sérico no diagnóstico precoce da insuficiência renal aguda induzida em cães. Anais X Conferência Sulamericana de Medicina Veterinária, Rio de Janeiro.

Williamson M.A. \& Snyder L.M. 2014. Wallach's Interpretation of Diagnostic Tests: pathways to arriving at a clinical diagnosis, interpretation of diagnostric tests. 10th ed. LWW, Philadelphia, p.9-10. 